\title{
Nest-Site Selection by Roseate Terns Breeding on Aride Island, Seychelles
}

\author{
JAME: A. RAMOS \\ Instituto Politécnico de Bragança, Escola Superior Agrảria, Campus de Santa Apolónia, \\ 5301-854 Braganga, Portaggal \\ Internet: jramos Wipb.pt
}

\begin{abstract}
Nest-site selection by tropical Roseate Terns (Sima dongallai) was examined on Aride Island, Seychelles. Continuous tariables reflecting concealment of the nest site, shelter, vegetation cerver atnd intraspecitic nest density were measured for nest-sites and random points. Seasonal variation in the initiation of nests with overhangs and their influence on hatching succes and adult intraspecific aggression towards chicks were aloo examined. Ro seate Terns selected nest-sites closer to taller vertical objects, and with a higher percentage of rocks, logs or branches overhanging the nest than occurred at random points. Nestsites in small colonies differed more from the available habitat than did those in the main colony. Nesting density was positively correlated with the amount of rock cover. On Aride and other colonies in the tropics Roseate Terns breed at higher densities than their temperate counterparts and spacing between neighbors may be a main factor in the selection of nest-sites, especially for birds nesting at the peak of the breeding season. Nest-site characteristics, notably overhangs, had no influence on hatching saccess. However, the proportion of ehicks that died from adult pecking was significantly lower in nests with overhangs. Concealment is a main factor of Roseate Tern nestsite selection throughout its breeding range, in both tropical and temperate areas, but the factors selecting for concealment seem to vary anongst colonies, On Aride conceal. ment appeared to be advantageous in defending territories and protecting young chicks from attacks of adults. Ar.

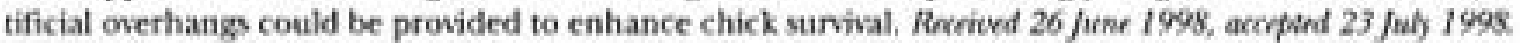

Key words.-Roseate Tern, Siena dongalli, nestesite selection, tropical tems, nesting densicy, Seychelles.

Colonial Waterbirds 21(3): 488-443, 1998

The study of nest-site selection is important on theoretical and applied conservation grounds. Breeding birds are confined to the nest-site during incubation and the chickrearing period, and the selection of an appropriate nest-site should allow birds to minimize the adverse effects of predation. inclement weather, or conspecific aggression, affecting reproductive fitness and survival (Partridge 1978). Nesting habitat may be artificially manipulated to enhance productivity of endangered species such as the Roseate Tern (Stema dougallii). Nest-site selection has been quite well studied in terns, including Roseate Terns in temperate areas (Burger and Gochfeld 1988a; Gochfeld and Burger 1988; Ramos and del Nevo 1995). Tropical Roseate Tern populations have received much less attention (but see Burger and Gochfeld 1988b). This study examines nest-site selection by Roseate Terns on Aride Island (Seychelles), where this species nests under a tree (Pisonia grandis) canopy (Warman 1979).

Habitat variables apparently selected by temperate Roseate Terns for nesting vary among colonies, but a common pattern is the selection of certain characteristics; for example, proximity to an elevated item such as a rock or tall vegetation, that provides nest-site concealment (Burger and Gochfeld 1988a, 1988b; Gochfeld and Burger 1988; Ramos and del Nevo 1995). Nest-sites in tropical colonies such as on Culebra, Puerto Rico, seem to be more open. There, Roseate Terns nest closer to conspecifics, farther from vegetation and with greater visibility indices than do those nesting in temperate areas (Burger and Gochfeld 1988b). This pattern may in part be explained by the greater availability of open habitats in tropical areas, since Roseate Terns on Culebra also select concealed sites: their nests are closer to overhanging rocks and to taller vegetation than would be expected by chance. Concealment may be beneficial against avian predators (Burger and Gochfeld 1988b) and nest-site competitors (Ramos and del Nevo 1995).

Despite some plasticity in nesting habitat by Roseate Terns (Ramos and del Nevo 1995), previous studies suggest that primary 
features of nest-site selection may be common to both temperate and tropical Roseate Tern populations. Therefore, it is important to study nest-site selection in additional tropical populations to understand patterns of nest-site selection and their driving factors. On Aride Island, two lizards, Wright Skink (Mabuya wnightit) and Seychelles Skink (Mabuya sechellensis), are the main egg predators (Ayrton 1994; Maul 1996; Ramos 1998), taking only unattended eggs (Ramos 1998). Avian predators are not present. Therefore, Aride Roseate Terns should have less need to conceal their nests.

Nest-site characteristics of Roseate Terns on Aride Island are described in relation to available habitat, to compare nest-site selection between tropical and temperate populations and to suggest possible manipulations of the habitat that could enhance breeding success of this endangered species (Gochfeld 1983; Nisbet 1989). The Indian Ocean is the world's stronghold for this species (Gochfeld 1983), but very litule is known about its ecology.

\section{METhoos}

Aride island $\left(4^{\circ} 10^{\circ} \mathrm{S}, 55^{\circ} 40^{\circ} \mathrm{E}\right)$, is a 73,2 ha Royal Sor ciety for Nature Conservation reserve rising to $151 \mathrm{~m}$. It is a denselywegetated granitic island, vegetated mainly with Pismia, and has a few open glade areas. Open glades were originally dominated by a sedge (Marscus bigularis) bat recently have been imaded by an acantha. ceous herb (Anitasia sp), which forms a dense mat of stems (Warman and Todd 1984). Open rocky areas are restricted to the seashore.

Tem populations in brecting pairs are estimated at 172,000 for Sooty Tern (Stema fiseati), 8,500 for Fairy Tern (Ggis alba), 110.000 for Lesser Noddy (Anows uenuinosisis), 5,600 for Brown Noddy (Anous ssobdus), 70 for Bridled Tern (Sirna anathetus) (Betts 1997) and 1,119 for Roseate Tern (Rames 1998). The Lesser Noddy and Fairy Tern nest in trees throughout the island, including above the Roveate Tern colonies. The Sooty Tem nests in open glades and under the enclosed tree canopy (Feare et at. 1997 ) about $20-30 \mathrm{~m}$ from the Rove. ate Tern subcolonies, and the Brown Noddy nests on boulders and in palm trees. There are lange numbers of Wright Skinks and Seychelles Skinks, which feed on feces, dropped fish and eggs of seabirds (Brooke and Houston 1983).

On Aride, Roseate Terns are known to nest in open glades and under the canopy of Pisania (Warman 1979), although the former habitat has not been used since 1993 (Ayrton 1994; Maul 1996). Prior to 1993, the larger colony (the lodge glade) was an open area. This area was invaded by Asystasis and cleared in 1993 to encourage Roseate Tems to nest, but was instead colonized by
Sooty Terns because Asystasia also inhibits Sooty Tern nesting (Feare $t a l$. 1997). The remaining open glades are orcupied by Sooty Terns, where their nesting densities are much higher than under the woodland canopy (Feare of al. 1997), so it is unlikely that Roseate Tems will re-nest in open glades.

This study was carried out from May to July 1997. Three colonies were located in 1997; "western woodlands" (a main colony and two sub-colonies), "bois tortue", and "western roosting rocks". The first two colonies were under a canopy of Prsomia and the third was in grass and open rock by the coast. Six clutches were found on the western roosting rocks but all eggs were abandoned soon after laying. The breeding population in the main colony of the western woodlands was estimated at 1,088 pairs (Ramos 1998). The two sub-colonies were small diecrete groups about $30-50 \mathrm{~m}$ distant from the main colony, having six and 12 nests, respectively. Bois tortuc, about $700 \mathrm{~m}$ from the western woodLand colony, had seven nests. Apart from some tree stems, there was little ground segetation within the woodland colonies; some fern patches adjoining the nesting area appeared too dense for terns to walk. through. Thereafter 1 refer to the larger western woodlands colony as the main colony and the others as small colonies.

Three study groups were defined: (t) the small cot onies, (2) two quadrats in the nain colony, an edge quadrat with $49 \mathrm{~m}^{2}$ and a center quadrat with $64 \mathrm{~m}^{2}$, and (3) an area of about $180 \mathrm{~m}^{2}$ around a blind in the main colony (blind area). Nests in the blind area were studied using low-disturbance methods. All nests were mapped at the time of exg-laying, from a permanent blind, erected on a tree trunk about one meter above the ground; and the fates of egrs and chicks were monitored daily. The no quadrats in the main colony were established with coner posts and sting, 16 days after the firs egg was seen (1 June). All nests in the quadrats and small colonies were marked with numbered pegs or wooden tonguedeprestors. The two quadrats were visually isolated from each other and from the blind area by rocky barriers: only birds in the one stady plot plus a few neighbors left their nests during the disturbance of each research visit.

Detailed nest-site eharacteristies were measured during 20-30 minute visits, between the 16 th and 20 th day after the first egg was seen, to mimimize disurbance. This occurred about eight to ten days after the peak of egg-laying, but nest-mapping from the blind showed that only nine eggs were lost before 20 June, with one being relaid. Since 148 nests were mapped prior to 18 June, and assuming an cqual proportion of egg loss in the blind area and quadrats plus small colonies, probably only about $5.4 \%$ of the nests were lost in the quadrats and the small colonies prior to nest-site characterization. This is a small error that would not have affected the study of nesting patterns.

For the small colonies and the edge quadrat, data were collected at all nests and at a similar number of random points, In the center quadrat, due to high nest density, nestsites and random points were characterized only in the first $16 \mathrm{~m}^{2}$ of the quadrat. For the edge and center quadrats of the main colony, the $x$ coordinate of the random points were established systematically (every meter) and the y coordinate randomly, using a table of random numbers. For the small colonies, the random points were determined by using a table of random numbers to generate $\mathbf{x}$ and $\mathbf{y}$ coordinates for the 
Table 1. Site variables recorded for nest sites and random points.

\begin{tabular}{|c|c|}
\hline Site varisable & Description \\
\hline Object distance & $\begin{array}{l}\text { Distance to the nearest vertical object (rock or log more than } 4 \mathrm{~cm} \text { high) from the } \\
\text { edge of the nest to the base of the rock or } \log (\mathrm{cm}) \text {. }\end{array}$ \\
\hline Object height & Height of nearest elevated object $(\mathrm{cm})$. \\
\hline Vegetation cover & Vegetation cover within 1 in radius of nest ( $\%$, visual estimation). \\
\hline Vertical object around nest & Vertical object around the nest within $30 \mathrm{~cm}$ ( $\%$. vistal extimation). \\
\hline Object overhanging & Object overhanging the nest ( $\%$, visual estimation). \\
\hline Visibility from above & Nest-site visible from above ( $\%$, visual estimation). \\
\hline Neighbor distance & Distance to nearest neighbor $(\mathrm{cm})$. \\
\hline
\end{tabular}

points. This slight difference in sampling was used be. cause the second technique should be more appropriate for sampling available habitat in an area where nests are more scattered. Seven continuous variables reflect. ing concealment of the nestaite, shelter, vegetation cov $e$ and intraspecific nest density were recorded (Table 1).

Characteristics of Roseate Tern nest-sites were compared against these of random points for the small col. onies, the edge and the center quadrats, and characteristics of ness of the main colony against those of the small colonies, using Kruskal-Wallis $\mathrm{H}$ tests. Hatching success was registered for each nest-site and characteristics compared between succestul and unsuc. cessful nests, using logistic regression.

In the blind area, the cegs-laying season was divided into two periods ( $1-6$ June and after 6 June). 1 noted whether or not each nest was placed under overhanging objects (rock or logs). Young ehicks could be pecked by adults if they wandered from the territory or when left unguarded by their parents. Young chicks which were seen dead or which disappeared after being badly pecked when last observed were regarded as hasing died from pecking. Overhanging objects provide protection from inclement weather and should minimize the effects of adult aggression; therefore, nest-sites with overhanging objects may be preferred (i.e. selected by the carliest breeders). A chiskinuare analysis tested the null hypotheses that nest-sites initiated within each cgslaying period had an equal frequency of nest-sites with overhanging objects, and that overhangs had no influence on chick mortality from adult pecking, Chicks infested with ticks (birds observed standing on one foot only) in the blind area, quadrats and small colonies were noted also.

\section{RESULTS}

\section{Nest-site characteristics on Aride}

In the small colonies, nest sites differed from random points with respect to all characteristics measured, while in the edge quadrat, five of seven characteristics differed, and in the center quadrat only four characteristics were significantly different (Table 2). In all plots Object distance, Object height and Object overhanging were the main variables distinguishing nest sites from random points
(Table 2). Roseate Terns selected nest-sites closer to taller vertical objects, and with a higher percentage of rocks, logs or branches overhanging the nest than were present at the random points. In small colonies, Roseate Terns selected nest-sites with a taller nearest vertical object, more vegetation cover, more vertical objects around the nest and more distant from the nearest neighbor than were present at nest-sites selected in the main colony.

The center quadrat had 1.23 nests $\mathrm{m}^{2}$ and the edge quadrat 0.63 nests $\mathrm{m}^{2}$. Aride Roseate Terns kept, on average, a minimum distance of about $0.5 \mathrm{~m}$ from the nearest neighbor. Neighbor distance was significantly correlated with object height $\left(r_{s}=0.27, P<\right.$ $0.01)$ and vertical object around the nest $\left(r_{s}\right.$ $=0.22, \mathrm{P}<0.05$ ). Observations from the blind showed that Roseate Tern individuals built several trial nest-cups within the territory. Among other possible variables that may have influenced the exact location of the definitive nest-site, the nature of the substrate (it is probably easier to make a nest cup if the ground is soft) and the aggressiveness of neighbors (five pairs were seen changing nest-sites after much aggression from neighbors) scemed important. Several such trial nest-sites seemed to be closer to the nearest neighbor than were the eventual nest-sites.

Overall, nest-site characteristics had no influence on hatching success (logistic regression, $X_{7}^{2}=8.08, P=0.33$ ). Hatching success in the small colonies $(44.0 \%, \mathrm{~N}=25)$ was lower than in the main colony (blind area, $56.7 \%, \mathrm{~N}=171$ ) but the difference was not significant $\left(X_{1}^{2}=2.21, P>0.05\right.$, Yates correction). Within the main colony, the hatch- 
ing success of the center quadrat was significantly higher than that in the edge quadrat $(73.8 \%$ and $51.1 \%, \mathrm{~N}=84$ and $\mathrm{N}=$ 45; $\mathrm{X}_{1}{ }_{1}=5.7, \mathrm{P}<0.05$, Yates correction), sug. gesting that factors other than physical characteristics of the nest-sites contributed to hatching

success.

In the blind area, there was no difference in the frequency of nest-sites with overhang initiated between the periods 1-6 June and after 6 June $\left(\mathrm{X}^{2},=3.0 . \mathrm{P}>0.05\right.$, Yates correction, Table 3). The presence of overhanging objects (rock or logs) did not have any significant effect on hatching success for both the periods $1-6$ June $\left(\mathrm{X}_{1}^{2}=0.63, \mathrm{P}>0.05\right.$, Yates correction) and after 6 June $\left(X_{1}^{2}=1.9, P>\right.$ 0.05 . Yates correction, Table 3 ), but it was significantly associated with the proportion of chicks that died from adult pecking (four chicks in nest-sites with overhang and 15 in nest-sites without overhang; $\mathrm{X}_{1}^{2}=5.26, \mathrm{P}<$ 0.05 , Yates correction). During this study virtually all chicks died from starvation, and there was extensive interference from neigh. bors and failed breeders during chick feeding (Ramos 1998). Some medium-sized chicks were seen hiding in overhangs or facing vertical rocks where they could swallow large prey without being robbed.

Chicks were also heavily infested with ticks (Amblyomma loculosum) in July. Of all marked nests, only two chicks fledged, from an isolated small colony without ticks.

\section{Comparison with Other Colonies}

In terms of physical features, nest-site characteristics on Aride were similar to that in the United States (Burger and Gochfeld 1988a; Gochfeld and Burger 1988), the Azores (Ramos and del Nevo 1995) and some colonies on Culebra, Caribbean (Burg. er and Gochfeld 1988b). Vegetation cover around the nest-site was a major difference between tropical Roseate Terns on Aride and those on Culebra. The beneficial effect of ground cover on Culebra was replaced by the tree canopy on Aride. Other tropical Roseate Tern populations seem to nest in more open areas: in the Virgin Islands on unvegetated ledges or sea-level coral rubble 
(Norton 1988), in Parguera, Puerto Rico, on barren coral rubble cays (Shealer 1995), in Tanzania and South Africa on bare coral rock or on mats of detritus (Thomas and Elliot 1973; Randall and Randall 1981), and on the Great Barrier Reef, Australia, on flat cays of coralline sand covered with grass, which the birds prefer for nesting (Milton $e t$ al. 1996), on low vegetated cays with Blacknaped Terns (Sterna sumatrana) (Smith 1991) and on bare sand near Black-naped Terns (Gochfeld, pers. comm.).

Mean nearest-neighbor distance found in this study is consistent with those found for other tropical colonies: $66 \mathrm{~cm}$ in South Africa (Randall and Randall 1981), $40.70 \mathrm{~cm}$ in Parguera (Shealer 1995) and 63-97 on Culebra (Burger and Gochfeld 1988b), but much smaller than those reported for temperate Roseate Tern populations: $80-126 \mathrm{~cm}$ in the Azores (Ramos 1990) and $143 \mathrm{~cm}$ in New York (Burger and Gochfeld 1988a).

\section{Discussion}

Nest-site selection by Roseate Terns on Aride resembled that of temperate and some tropical counterparts. Tropical Roseate Terns seem to select concealed nest-sites if they are available, but are not constrained from nesting in open areas (Shealer 1995).

Social factors are important in the selection of nest-sites since Aride Roseate Terns nested, on average, as close as $0.5 \mathrm{~m}$ to neighbors, when many concealed sites were available around the colony. At high nest densities, fewer variables differed between nest-sites and available habitat, suggesting that peak-nesting birds were unable to select nest-sites differing in physical features from the available habitat, due to the proximity of neighbors.
Distance to the nearest neighbor was positively influenced by the amount of rock cover in the area, suggesting that a rugged terrain will accommodate more breeding birds. Tropical Roseate Terns are more aggressive than temperate counterparts (Burger and Gochfeld 1988c; Shealer 1995; pers. observations). This has been viewed as a reflection of the more exposed nesting habitats in tropical areas (Shealer 1995), but could simply be a reflection of higher nest densities in tropical areas. Higher nest densities may also make social stimulation more important for Roseate Terns breeding in the tropics.

Predation and inter-specific competition have been invoked to explain variability in nest-site selection by temperate and tropical Roseate Terns (Burger and Gochfeld 1988a,b; Ramos and del Nevo 1995). On Aride nest-site characteristics, notably overhangs, had no influence on hatching success and predation or inter-specific competition could not explain concealment. The higher hatching success in the center quadrat may be explained by older and more experienced birds presumably nesting in the center of the colony (Coulson 1968; Burger et al 1996). Ectoparasites were present on Aride and may also influence nest-site selection, but this needs evaluating.

Although the primary features of nestsite selection are common to both temperate and tropical Roseate Terns, the reasons behind nest-site selection may vary among colonies. If not for other reasons, concealment may be less stressful for breeding adults. The location of a nest-site should be viewed as a dynamic procedure depending on the aggressiveness of the neighbors, the softness of the ground to make a nest cup, and vegetation and rock cover. Finally, the benefits of nest-site selection to Roseate Terns may be

Table 3. Seasomal variation in the hatehing stuccess of Roseate Terns in relation to nests with and without overhang.

\begin{tabular}{lcccc}
\hline \hline Nests initiated within & Number of nests & $\%$ with overhang & Hatching success and overhang (blind area) \\
\hline & 79 & $\%$ with overhang that $\%$ without overhang \\
that hatched
\end{tabular}


difficult to quantify with conventional approaches like the one used in this study. It may be necessary to record adult and chick behaviors and relate them to nest-site features, to deepen our understanding of nestsite selection.

In practical terms this study suggests that partial overhangs may reduce chick mortality from adult aggression. Artificial shelters increased the reproductive success of temperate Roseate Terns (Spendelow 1982) and could be used in the tropics.

\section{ACKNOWTHECLENTS}

I am indebted to Dr. James Cadbury of the RSNC for permission to carry out research work on Aride and for financial assistance to travel to Aride. The wardens of Aride, Mike Betts and Susan Barclay, introduced me to the isfand and their birds: their help. friendship and "coconut loafl" are gratefully acknowledged. This work was possible with the great help of Paul Burton and Rob Malvom. This paper was improved by the helpful com. mens of Michael Gochfeld, Tony Diamond and Dasid Duffy. Finally I must thank my wife Lucia for her con. tinuing support.

\section{Lmerature CITB}

Ayrton, V. 1994. The 1994 Roseate Tern breeding sea. son-Aride Island. Report to the Royal Society for Nar. ure Conservation, Lincoln, UK.

Bets, M. 1997. Aride Island scientific report 1956. Report to RSNC, Royal Society for Nature Conserva. tion, Lincoln, UK.

Brooke, M. de L. and D. C. Houston. 1983. The biology and biomass of the skinks Mabisya sechellensis and Mabuya wrightij on Cousin Island, Seychelles (Reptil. ia. Scincidac). Journal of Zoology, London 200; 179. 195.

Burger, J. and M. Gochfeld. I988a. Nest site selection and temporal patterns in habitat use of Roseate and Common Terns. Auk 105: 433-438.

Burger, J and M. Cochfeld. 1988b. Nest-site selection by Roseate Tems in two tropical colonies on Culebra. Puerto Rico, Condor 90: 843-851.

Burger, J. and M. Gochfeld, 1988c, Defensive aggression in tems: effect of species, density, and isolation. Aggressive Behaviour 14: 169-178.

Burger, J., I. C. T. Nisbet, C. Satina and M. Cochfeld. 1996. Temporal patterns in reproductive success in the endangered Roseate Tern (Sterva dougallai) nesting on Long Island, New York, and Bird Island, Mas. sachusetts. Auk 113: 131-142.

Coulson. J. 1968. Differences in the quality of birds nesting in the centre and on the edges of a colony. Na. ture 217: 478-479.

Feare, C. J., E. L_ Gill, P. Carty, H. E. Garty and V. J. Ayrton. 1997. Habitut use by Seychelles Sooty Terns Sier. na fuscala and implications for colony management. Biological Conservation 81: $69-76$.

Gochfeld, M. 1983. The Roseate Term: world distribution and status of a threatened species. Biological Conservation 25: 103-125.

Gochfeld, M. and J. Burget. 1988. Nest site selection: comparisons of Roseate and Common terns (Sima dougollii and $S$. hirando) in a Long Island, New York colony. Bird Behavior 7: 58-66.

Maul, A. M.1996. Aride Island seabird report May-August 1995. Report to the Royal Society for Nature Conservation, Lincoln. UK.

Mition, D. A., G. C. Smith and S. J. M. Blaber. 1996. Vartable success in breeding of the Roveate Tern Semna dougultai on the Northern Great Barrier. Emu 96: 123-131.

Nisbet, L. G. T. 1989. Status and biology of the North Eastem population of the Roseate Tem Suma dougalli. A literature survey and update: 1981-1989. Un. published report U.S. Dept, of interior, Fish and Wildlife Service, Office of Endangered Species, South Hadley, MA.

Norton, R. L 1988. Extra-egg clutches and interspecific exg-dumping of the Roseate Tern (Sterna dougatii) in the West Indies. Florida Field Naturalist 16: 67-70,

Partridge, L. 1978. Habitat Selection. Pages $351-376$ in Behatiourel Ecologh an evolutionary approach (J. R. Krebs and N, B. Davies, Ed.), Sinauer Associates, Sunderland, MA.

Ramos. I. A. 1990. Colony and nest site selection by Roseace and Common Terns in the Amores archipelago: a multivariate amalysis. M. Sc. thesis. University of Durham, Durham, UK.

Ramos. J. A. 1998. Breeding ecology of Roseate Terns on Arbde Land, Seychelles, in 1997. Report to the Roy. al Society for Nature Conservation, Lincoln, UK.

Ramos. J. A and A.J. del Nevo. 1995. Nestsite selection by Roseate Terns and Common Terns in the Azores. Auk 112: 580-589.

Randall, R. M. and B. M. Randall. 1981. Roseate Tern breeding biology, and factors responsible for low chick production in Alagoa Bay, South Africa. Ortrich 52 : 17.24.

Shealer, D. A. 1995. Comparative foraging ecology of Roseate and Sandwich Tems in Puerto Rico and its relation to breeding performance. Ph.D. thesis. Rutgers: the State University of New Jersey, New Brun. swick, N].

Smith, G. C. 1991. The Roseate Tem Sima dougallai breeding on the Northern Great Barrier Reef, Quecnsland. Corella 15: 39-36.

Spendelew, J. A. 1982. An analysis of temporal variation in, and the effects of habitat modification on, the re productive success of Roseate Terns. Colonial Waterbirds 5: 19.31.

Thomax, D. K. and H. F. I. Elliot. 1973. Nesting of the Roseate Tern (Serne dougallis) near Dar er Salaam. Bulletin of the British Orrithologists Club 93: 21-23,

Warman, S. R. 1979. The Roseate Tern Stema doageltii aridensis on Aride Island, Seychelles. Bulletin of the British Omithologists Club, 99: 124-128,

Warman, S. R. and D. Todd. 1984. A biological survey of Aride tsland Nature Reserve, Seychelles. Biological Conservation 28: 51-7!. 